\title{
WHO WAS FATHER MAZZUCHELLI?
}

\author{
By John R. Adney \\ Miles, lowa
}

The Midwest knows him as "The Steam Engine" and as "The Builder of the West" because it was in this area that he exercised his zeal and talents. He was many things: theologian, scientist, educator, historian, architect, author and missionary. More than a score of schools, churches, court houses, a Market House and Capitol trace to him their blueprints and transformation to actuality.

Born in Milan, Italy, Nov. 4, 1806, Samuel Charles Mazzuchelli entered the Dominican Order and came to the United States as a volunteer after learning of the need for priests and teachers in America.

He was one of the passengers who disembarked on Nov. 14, 1828, from the "Edward Quesnel" at New York harbor. Arriving unexpected and unwelcomed, it was with relief that after a short delay he found himself on his way to Philadelphia and Baltimore, whence by stagecoach and riverboat he traveled the remaining 600 miles to his destination, Cincinnati.

During the journey he experienced the great inconvenience of not knowing the English language. An American gentleman perceived his embarrassment in the stations and inns because he could not make himself understood. Feeling sorry for the foreigner, the man indicated by signs that he would pay for everything and make all arrangements for travel as far as Cincinnati and there he would show him how much had been spent. After reaching his destination the kind protector wrote on a paper the sum he had paid on the journey, but seeing his fellow traveller did not have sufficient money, made him a sign to go on to the Catholic Church which could be seen nearby. 
A professed member of the Order of Preachers since Dec. 6,1824 , he enjoyed fraternal companionship only until he received full priestly powers from Msgr. Edward Fenwick, the venerable bishop of Cincinnati, on Sept. 5, 1830, and was sent at once to Mackinac Island 600 miles distant. From this outpost on Mackinac Island, Father Mazzuchelli served also the people of the Green Bay-Fort Winnebago region until 1834 .

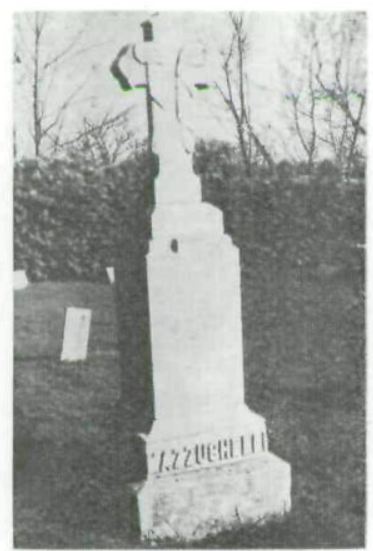

Courtesy Santa Clara Convent Marker at Benton, Wis.

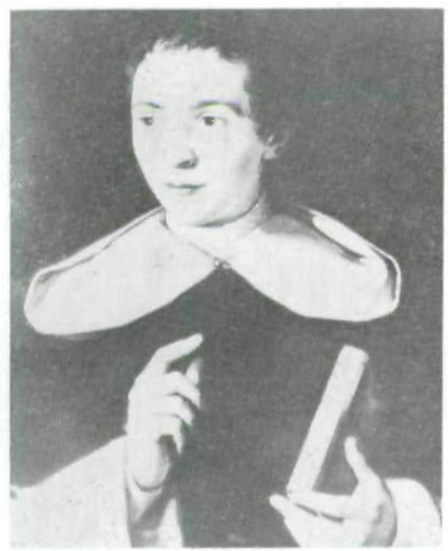

Courtesy Santa Clara Convent Father Mazzuchelli

Sister Mary Paschala O'Connor, writing in her book Five Decades, informs us that, "Father Mazzuchelli was the first resident pastor of Mackinac Island and that first winter of his assignment proved to be a period of orientation for the lifework awaiting him: preaching, teaching, building. There, within the island's circumference of eight miles, he first exercised his priestly powers among Canadian-French and Indians whose spiritual life centered in the half-century old St. Ann's Church but had had only occasional stimulus through visits of priests from Detroit. The crude domestic conditions prevailing among the aborigines were apparent in the Indian Village along the west shore of the island, and from the smoking lodges often rose the unhallowed din which marked the lowest depth of savage degradation-resort to demonalotry for relief in sickness, success in war, or revenge for unrequitted affections." 
"The deprivation of the light of the Gospel," Father Mazzuchelli was later to write in his Memoirs, "leaves them in that spiritual darkness which is the cause of their imperfect idea of the Divinity. . and throws them into that jumble of superstitions which constitute their religious system."

The parish of Mackinac was favorably situated for the conversion of Indians, many of whom came from the adjoining regions to hear the religious instructions given in their own language through an interpreter. In the spring of 1832, 50 of them were members of the Catholic Church. To facilitate their conversion, they were invited to the church at Sunday Vespers where they sang alternately one verse in Latin and the next in Indian.

"The holy feast of Easter in 1832," wrote Father Mazzuchelli in his Memoirs, "saw more than 100 communicants who a few months earlier, dead to grace for many years, had been callously walking on the road toward final impenitence."

"It was spring for the church in Wisconsin," says Sister Mary O'Connor, "when Father Mazzuchelli arrived at Green Bay in May, 1831. Over a century earlier this neglected field had been cultivated by the Jesuit missioners, but now only the name, Rapides des Peres, identified the river-site of their St. Francis Xavier Mission House which had been destroyed by hostile Indians in 1687."

Bishop Fenwick followed Father Mazzuchelli to Green Bay where the Bishop and priest preached a mission; Father Mazzuchelli wrote of this visit in his Memoirs, "The day was not long enough; it was necessary to supply time by working a good part of the night, hearing confessions. But the Holy Feast of Pentecost saw many approach the Most Holy Sacrament who had almost forgotten it; more than 40 Indians were regenerated in the waters of holy Baptism."

For the Winnebago Indians he prepared, in 1833, a prayer book intended to serve as a reader in the school which he opened for this tribe. His Chippewa Almanac, the first book printed in Wisconsin, was published in 1834 in Green Bay to teach the Indians the elements of astronomy and the Christianised year. 
His Diocese spread over countless miles, and life was harsh. He traveled by canoe, snowshoe, horseback and on foot and was often cold, lonely and hungry. Those who knew him said he often fought loneliness by remembering the great cathedrals of Rome and Paris as he offered Mass on log altars in wigwams and huts.

Because he often stayed where there were no beds, Father Mazzuchelli practised for this strenuous life by sleeping on the floor beside his cot. Renouncing the comforts of his native Milan for the rude, fatiguing life of the new-world wilderness, he scorned the American dollar for personal gain, but lived under its motto: "In God We Trust."

Beautiful buildings, several schools and a convent remain today to remind us of Father Mazzuchelli. In Dubuque, the site of the Cathedral is the same as that chosen by him for the cathedral he built in the middle 1880's. The original cornerstone of St. Mary's Catholic Church contains a sermon which the priest gave the day the first shovel of earth was turned.

"In a country where commerce, the arts, the cities, and society itself are in their infancy," wrote the priest in his Memoirs, "the erection of churches becomes a work not only of grave importance to the propogation of the faith, but also an undertaking difficult to accomplish. The scarcity of the necessary funds, the impossibility of procuring indispensable materials on the spot, the exorbitant wages of workmen, and various other circumstances test the perseverance and industry of one who tries to build even a small house of the Lord."

During the summer of 1836, the walls of St. Raphael's church, now the Cathedral of Dubuque, were erected and Father Mazzuchelli said the first mass in the unfinished church on July 31, 1836.

Because the Missionary was occupied on the western bank of the Mississippi during the summer of 1836, it was difficult for him to find time to urge on the construction of the church of St. Michael in the little town of Galena; nevertheless there, too, the walls were raised to a height of several feet. 
Services were held in various houses of the village where it was most suitable, but to provide a more useful and permanent place a small, wooden house was built on the church land. Until 1839, this served as a chapel and dwelling for the priest. The stone church, begun in 1835, was completed in 1842.

In his Memoirs, Father Mazzuchelli reported building a tiny $20^{\prime}$ by $30^{\prime}$ church in the town of Bellevue upon the western bank of the Mississippi in 1842. The church, dedicated to St. Andrew the Apostle, stood little over a decade before fire destroyed it.

Thanks to a considerable number of colonists from Europe and the eastern states of America, the vast uncultivated fields in the vicinity of Dubuque were beginning to change in appearance. The woods were falling beneath the axes of the new settlers who were intent on deriving profit from the meadows that were changed by the plow into fields covered by plentiful harvests. Among the most noteworthy sites where Catholics had immigrated was Maquoketa in Jackson County.

In 1840, Father Mazzuchelli considered it his duty to go to Maquoketa and build a church which, because of the poverty of the settlers and the abundance of timber, had to be of wood. Unable to contribute money, the Irish families that had settled there to earn the bread denied them in their own oppressed land, assisted in many ways to lessen the expense of the new church. Bishop Matthias Loras, first bishop of Dubuque, contributed $\$ 600$ from the contributions of the Propagation of the Faith funds to procure materials and pay workmen employed by Father Mazzuchelli to erect the structure which was dedicated to St. Patrick, the Apostle of Ireland. When services were first held in the summer of 1840, there were no more than 100 Catholics; three years later the parish contained "six hundred souls" and had a school.

When Father Mazzuchelli established a church, he served as architect, contractor, superintendent, fund raiser, and often as laborer. It was not considered strange to see the priest mixing mortar one day and conferring with well-known legislators the next. 
Besides being a priest and missionary whose sermons were known for their practicality, he became an outstanding architect. Although he is most known for his churches, he also designed the courthouses at Galena and Ft. Madison and the Galena Market House.

Many believe him to have been the architect of Old Capitol and its magnificent two-story spiral staircase at Iowa City, but the building guards its secret well as lack of definite proof continues to shroud his part in its design. Even today, visitors to Old Capitol receive a brochure attributing architectural influence to "Father Mazzuchelli, a priest who worked among the Indians on the frontier and was a student of classical architecture."

Sister Mari, O. P., informs us in Father Mazzuchelli in Iowa City, that, "Father Mazzuchelli himself in the Memoirs merely stated the basic outline of the plan to build the State House. At no time does he claim or disclaim credit for the building, although it is evident that he was thoroughly knowledgable on every aspect of its construction, from raising money to purchase materials to precise measurements and placement on its choice site."

"After the Memoirs," Sister Mari continues, "the earliest extant statement concerning Father Mazzuchelli’s work occurs in the Iowa Historical Record of July, 1888: 'Rev. Samuel Mazzuchelli drew the plan for the Capitol building and John F. Rague was afterwards the architect and he had the contract for its erection but after doing about ten thousand dollars worth of work, nearly completing the basement, he threw up his contract and abandoned the work." "

The question of the identity of the architect has been controversial for many years. Whether or not Father Mazzuchelli actually designed the historic structure, he undoubtedly was associated with Mr. Rague. And the noted priest certainly had an important part in the designing of Iowa City's famous boulevard, Iowa Avenue, which a national magazine editor described as the "handsomest" boulevard of any city of Iowa City's size in the United States. University authorities have confirmed the role filled by Father Mazzuchelli in the enterprise. 
"The habit of many of linking him and the Old Capitol seems to persist," Sister Amata, Archivist of St. Clara Convent, wrote recently, "I suspect that from Heaven he may be amused since credit for the achievement was unimportant to him. It was the accomplished task that mattered, not the doer of it."

If for Father Mazzuchelli it was the deed, not the doer that mattered, whether the mystery is ever solved is ultimately unimportant. Yet the tradition lives on and the search continues for documents to prove Father Mazzuchelli's role in designing Iowa City's Old Capitol.

In April, 1837, he blessed the site and laid the first stone of Davenport's first church - St. Anthony's, a building he had designed.

In Antoine Le Claire's first addition to the new village, he designated a "Church Square" four blocks from the waterway and one block East of the Harrison St. boundary. Here the simple $25^{\prime}$ by $40^{\prime}$ church was constructed from the first brick made in Davenport and finished in the spring of 1839.

The year before, Father Mazzuchelli offered the area's first Mass to the 14 or 15 Catholics living in Davenport and Stephenson (now Rock Island), Ill. Most of those who gave confession and received communion that spring morning in 1836 hadn't seen a priest for five or six years. So Father Mazzuchelli also baptised children and blessed weddings. All this took place at Le Claire's home, since there was no church.

Years later, writing in his Memoirs in Milan, Italy, Father Mazzuchelli observed of Davenport:

"Among the most beautiful and charming sites on the western banks of the Mississippi is that one opposite a famous Rock Island, more than a hundred miles from Dubuque down the river. Nature herself seems to have shaped this regular verdant slope, girdled and shielded by hills, that man might raise a city."

He tried many methods to promote the faith. In Feb., 1843, he traveled to Nauvoo, Ill., in the hope of converting the Mormon leader Joseph Smith to Catholicism. The visit 
provided material for a detailed description of Mormon belief for his Memoirs - but no conversion. The priest left there well informed on Mormon teaching but sorrowful about what he considered the fanaticism of a man who declared that he had seen God many times face to face and that his own sanctity equalled that of St. Paul.

One time, he visited the Winnebago Indians at a place called Decari, after its tribal chief. The area was infested with rattlesnakes whose bite was venemous and often deadly. One morning the priest had scarcely opened his eyes when he discovered a serpent coiled around a beam which crossed the lodge. Knowing that the snake would not attack unless molested, he waited calmly until it crawled through an opening in the wall.

Another time, while instructing a sick man, he sat on the ground for more than half an hour. On rising to leave he found an enormous rattlesnake coiled up under his cassock. The Indians who were there gave a great shout and in an instant had killed the unoffending but poisonous reptile.

On Sept. 28, 1814, he purchased Sinsinawa Mound in the southwestern corner of Wisconsin where he founded the community of Dominican Sisters of the most holy Rosary of the Third Order of St. Dominic. Located here is the motherhouse for 2,000 Dominican nuns serving in 135 missions in the United States, Bolivia, Switzerland and Italy.

In 1852 he turned his attention from his Sinsinawa Mound College to found St. Clara's Female Academy at Benton, Wisconsin; here he began to instruct high school girls in subjects that were reserved for college study — and then only for men. A gifted and far-seeing educator, Father Mazzuchelli envisaged cultured and thoroughly educated graduates. $\mathrm{He}$ earned the reputation of "Father of science in Wisconsin" with teaching aids far in advance of their time.

Notations in his account book for 1856 show a series of lectures he was to give that year: Division of Celestial bodies, Centrifugal and Centripetal power, the general idea of Astronomy, Magnetism and The Signs of the Zodiac. His prominence as a teacher of science was attained with no formal education beyond seminary training in Rome. His ad- 
vanced teaching techniques earned him the credit of having introduced the laboratory method of teaching science in Wisconsin.

Stories of Father Mazzuchelli's courage are numerous. His first horseback ride was a trip of nearly 40 miles made without rest. While crossing the Atlantic Ocean in 1828, he had himself lashed to the ship's mast so that he could observe nature at its wildest. He once traveled 225 miles in eight days, collecting dew in a cup when there was no water.

On a blustery winter day in 1864 he ignored the weather to answer an urgent sick-call, hurrying to his country parishioner without regard to his own unpreparedness for the cold ride. "The chill he subsequently suffered," writes Sister Mary Paschala 'O'Connor, "could not be ignored. Soon in awed whispers the Sisters reported the medical diagnosis to inquires: 'Pleuro-pneumonia'."

Father Mazzuchelli never recovered from his illness, but his death was not unwelcomed. Sister Mary tells us that on the Sunday previous to his departure from this world he fell into a slumber; shortly he awoke, endeavoured to raise himself to his feet and exclaimed: "O Good Mother!" Tears of joy rolled down his cheeks in torrents. Then for some time he appeared rapt in profound meditation, after which he again burst forth into tears of joy. Being asked what was the matter he replied "Oh; nothing but happy thoughts. God grant that I may have them in my last moments!" and addressing himself to the Sister who questioned him he said, "If you saw a person who had been on a long, painful journey, separated from his friends and home, and he found himself at the end of that journey, and got a glimpse of home, would you not allow him to rejoice?"

Father Mazzuchelli died Feb. 23, 1864. In the corner of the churchyard nearest St. Patrick's Church in Benton, Wisconsin is his grave, still a place of pilgrimage. A simple, cross-crowned shaft is the only marker, but with the tenacity of granite, it preserves the murmured confession of joy with which he exchanged exile for home: "Quam dilecta, tabernacula tua, Domine, Virtutum."”

"trans. "With what delight your tabernacle, O virtuous Lord." Ed. 
Copyright of Annals of Iowa is the property of State of Iowa, by \& through the State Historical Society of Iowa and its content may not be copied or emailed to multiple sites or posted to a listserv without the copyright holder's express written permission. However, users may print, download, or email articles for individual use. 